\title{
Recovery of an Estuarine Ecosystem after the Stopping of Wastewater Discharge: Intertidal Macrobenthic Community Characterization in the Estuary of Oued Souss (Southwestern Morocco)
}

\author{
Hafida Bergayou ${ }^{1 *}$, El Mehdi Anajjar', Latifa Lefrère', Abdellatif Moukrim', \\ Patrik Gillet $^{2}$ \\ 1 Laboratory Aquatic Systems: Marine and continental ecosystems; Faculty of Sciences, PB 8106, \\ Ibn Zohr University, Agadir, Morocco \\ 2 Center for Studies and Research on Aquatic Ecosystems, Institute of Biology and Applied Ecology, \\ Catholic University of the West, BP 808, 44, rue Rabelais, 49008 Angers 01, France \\ * Corresponding author's e-mail: h.bergayou@uiz.ac.ma
}

\begin{abstract}
The communities of benthic macroinvertebrates, living in the estuary of Oued Souss (Agadir Bay, Morocco), were studied in parallel with the changes that this ecosystem had underwent after the stopping of pollution, caused by untreated wastewater discharge which occurred in November 2002. Three campaigns were undertaken during the summer season. Two of them were carried out while the estuary was receiving wastewater discharge in 2001 and 2002. The 2003 campaign was carried out after the cessation of the pollution. The intertidal macrobenthic fauna shows a similar faunal composition for both seasons during the period when the ecosystem was receiving wastewater discharge. During this period, Hydrobia ulvae was the dominant species, followed by Hediste diversicolor and Scrobicularia plana in decreasing order. In 2003, the number of individuals harvested was significantly larger compared to the period when the ecosystem received wastewater. For the dominance of species, $H$. diversicolor was dominanted, followed by H. ulvae, Cerastoderma edule, and S. plana in decreasing order. However, in both periods: before and after the end of wastewater discharge, the phylum of mollusks is dominant, followed by that of Annelids and Crustaceans. The study of the coenotic affinity between settlements of different radials allowed us to separate 2-3 groups of radials in 2001 and 2002, respectively, and 3 groups after stopping discharges in the estuary. The specific richness was greater in the year following the end of discharges (22 species in 2003 instead of 14 found during the pollution period: 2001-2002). The longitudinal distribution of the species living in this site in 2001 and 2002 became wider in 2003 and average biomass, determined by the study of the ash-free dry weight, became clearly greater $\left(20.46 \mathrm{~g} / \mathrm{m}^{2}\right.$ in 2003 ; and $15.54 \mathrm{~g} / \mathrm{m}^{2}$ or $15.84 \mathrm{~g} / \mathrm{m}^{2}$ in 2001 or 2002 respectively). This investigation allowed us to acquire a qualitative (species list, species richness) and quantitative (abundance, biomass, species density) database of intertidal benthic macrofauna of the Oued Souss estuary. It represents a reference state. It responds to the requests for information about the quality of the environment immediately after the cessation of wastewater discharge and could serve as a basis for conducting impact studies later.
\end{abstract}

Keywords: estuary, wastewater, intertidal macrobenthos, specific richness, biomass.

\section{INTRODUCTION}

The estuarine ecosystems are part of most productive coastal environments but remain the most vulnerable due to the exposure to toxic anthropogenic effluents transported by rivers from remote and nearby conurbations, as well as industrial and agricultural areas.

The Oued Souss estuary $\left(30^{\circ} 21^{\prime} \mathrm{N}, 9^{\circ} 35^{\prime} \mathrm{W}\right)$, located in an arid zone and part of Souss-Massa National Park (Ramsar site), constitutes one of the rarest humid areas in South Western Morocco. 
It is an ecosystem of great ecological interest, particularly for many migratory birds (Dakki et al., 1995; El Bekkay, 2013; Oubrou \& El Bekkay, 2014). However, the estuary experienced a profound ecological change. For a long time, it has been subjected to the discharge of large amounts of sewage and industrial effluents (Moukrim et al., 2000). Since November 2002, the establishment of a sewage treatment plant marked the end of wastewater discharge in the estuary (Ait Alla et al., 2006a).

The period in which the estuary was receiving the discharges has been the subject of several studies (Mimouni et al., 2002; El Hamidi et al., 2002; Gillet et al., 2003; Bergayou \& Moukrim, 2005). The investigations after the establishment of the plant are of interest because not only do they allow to compare the situation of the mouth of the valley before the end of the wastewater discharge but also to follow the evolution of the restoration of the ecosystem. It is within this framework that our laboratory has set up a multidisciplinary research program covering all the components of the ecosystem. Thus, the research focused on the physico-chemistry of water and sediment, heavy metals (Anajjar et al., 2008; Moukrim et al., 2008), pesticides (Agnaou et al., 2014), biomarkers (Ait Alla et al., 2006b; Bergayou et al., 2009), population dynamics and the biology of some species (Ait Alla et al., 2006a; Bergayou et al., 2008). Our investigations were conducted within the framework of this research program. The aim was to study the benthic invertebrate communities of the intertidal zone of the estuary during the wastewater discharge period $(2001,2002)$ and after their termination (2003). The analysis focused on the faunal composition, longitudinal distribution of species, species richness, abundance, dominance and biomass. It also enabled to define and compare the biocenotic units during the two periods.

\section{MATERIALS AND METHODS}

Three campaigns were undertaken during the summer season. Two of them were carried out while the estuary was receiving wastewater discharge in 2001 and 2002. The 2003 campaign was carried out after the cessation of the pollution. In order to ensure a good coverage of the ecosystem through our samples, 12 radials along the estuary and part of Oued Souss were defined. The radials were numbered from 0 to 12 from the mouth to upstream with radial 7 being the direct receptacle of wastewater during the discharge period (Figure 1).

Downstream from radial 2, the 1 bis and 2 bis stations belong to an arm of the Oued. Between radial 2 and radial 6 , the mudflat is wide, and the bed of the Oued shows sandbanks which very often are accessible. This is why we generally chose four sampling points by radial: two on the north bank (A, A') and two on the south bank (B, B'). From radial 6 going upstream, the mudflat decreases. Therefore, we selected only two points of sampling by radial: one on each bank.

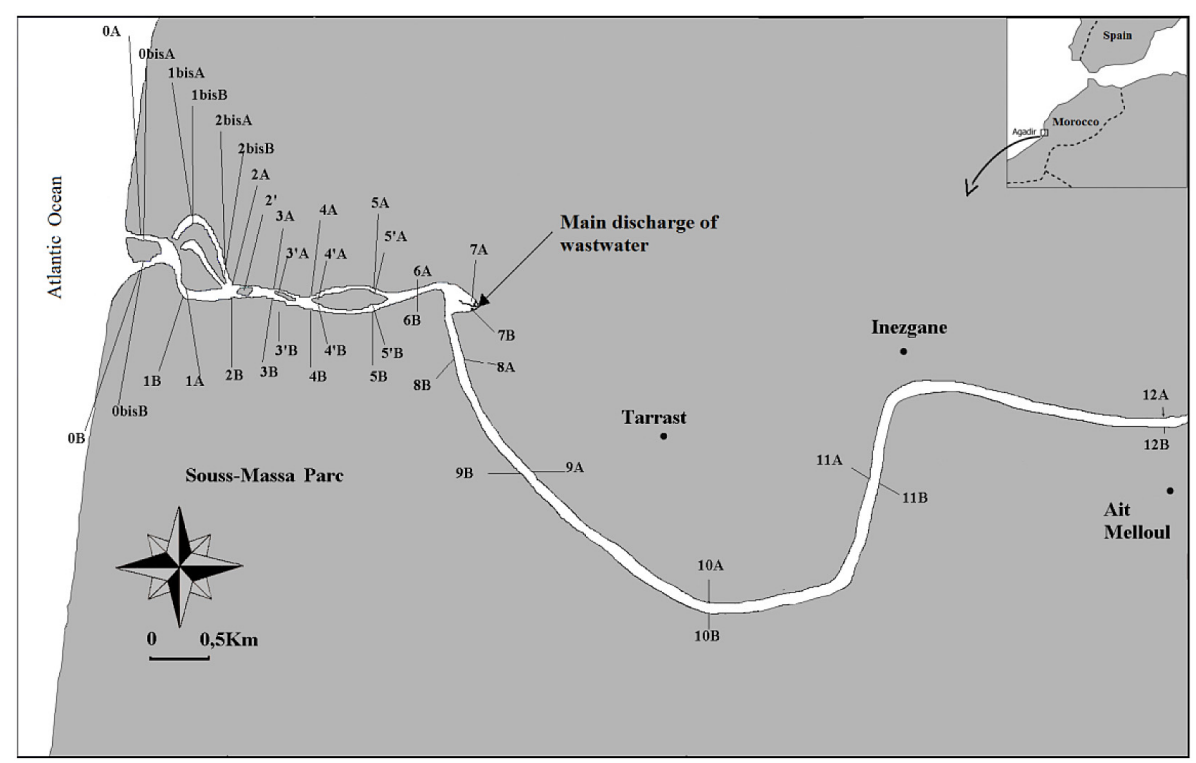

Figure 1. Location of the sampling stations of the intertidal macrobenthos in the Oued Souss estuary (Agadir Bay, Morocco) during the summer campaigns in 2001, 2002, and 2003. 
A total of 36 and 39 stations were sampled at low tide during the period before and after the discharges were terminated, respectively. Their coordinates were recorded using a GPS (MLR brand, type SP12X). During the last campaign, three additional stations were selected (0 bis A, Obis B, and 2'). They are the result of marine hydrodynamics that have made new sandbanks appear. Finally, it should be noted that after the discharges stopped, there was a modification of the watercourse that no longer reached radial 7 . The sediment samples $\left(0.0625 \mathrm{~m}^{2}, 20 \mathrm{~cm}\right.$ depth $)$ were collected at low tide according to the method of quadrats used by Elliot \& Descamps (1973).

The sorting of the different species was carried out on site or in the laboratory, using a sieve with $1 \mathrm{~mm}$ mesh. The animals were kept in ethanol at $70^{\circ} \mathrm{C}$ and their determination was carried out using a binocular magnifier and, in some cases, using a microscope (to study the morphology of the parapodia of some Annelids).

As a first step, the inventory of fauna, the spatial distribution of species, and parameters such as abundance (number of individuals of a species in a sample); the dominance (percentage represented by a species, a class, or an embranchment in a sample) that enable reconstructing the faunistic composition, were determined. Species richness (number of species present in the settlement) as well as biomass was also evaluated. For the last parameter, we performed a prior decalcification to the mollusks in a $10 \%$ hydrochloric acid bath and a drying at $80^{\circ} \mathrm{C}$ of all the individuals over 48 hours (to measure the dry weight). The animals were then placed in an oven at $600^{\circ} \mathrm{C}$ for 2 hours to reduce them to ashes. The difference between the decalcified dry weight and the ash quantity corresponds to the dry weight of the soft masses (ashless), expressed in $\mathrm{g} / \mathrm{m}^{2}$ (Bachelet et al., 1981).

In order to define biocenotic units, a hierarchical ascending classification was performed. For this, we first calculated the coenotic affinity between the station communities estimated from the Jaccard coefficient (Gillet, 1986): [ $\mathrm{J}=\mathrm{Na}$, $\mathrm{b} /(\mathrm{Na}+\mathrm{Nb}-\mathrm{Na}, \mathrm{b})]$ with $\mathrm{Na}$ : number of species in sample survey a, $\mathrm{Nb}$ : number of species in sample survey $b, \mathrm{Na}, \mathrm{b}$ : number of species common to sample surveys: $a$ and $b$. The different values are grouped in a similarity matrix from which the dendogram is built according to the algorithm: $\mathrm{dhij}=0.625 \mathrm{dhi}+0.625 \mathrm{dhj}-0.25 \mathrm{dij}$ (Lance \& Williams, 1967). This method is highly recommended by various authors (Legendre \& Legendre, 1998).

\section{RESULTS}

\section{Settlement faunistic composition}

\section{The ecosystem receiving wastewater discharge}

The macrobenthic fauna shows a similar faunal composition for both seasons during the period when the ecosystem was receiving wastewater discharge. The number of individuals, all species combined, amounts to 11270 and 9131 for 2001 and 2002, respectively (Table 1). The molluscan phylum largely dominates the settlement with $77.6 \%$ (in 2001) and $84.1 \%$ (in 2002). The rest of the benthic fauna is divided between the Annelids (21.82\% in 2001 and $12.42 \%$ in 2002), the Crustaceans $(0.57 \%$ in 2001 and $3.18 \%$ in 2002) and the Nemathelminthes, which constitute a minority and are identified only in 2002 (less than 1\%).

The ecosystem is poor in terms of biodiversity (Table1). Only a limited number of species $(\mathrm{N}=14)$ are encountered. However, these species are abundant. Thus, Hediste diversicolor, Hydrobia ulvae and Scrobicularia plana, alone represent more than $94.5 \%$. In fact, in descending order, $H$. ulvae has an abundance of about 6500 and 6730 and densities of up to $7016 \mathrm{ind} / \mathrm{m}^{2}$ and $8088 \mathrm{ind} / \mathrm{m}^{2}$ for 2001 and 2002, respectively; followed by $H$. diversicolor with abundances of 2426 and 1112 and densities of up to $1464 \mathrm{ind} / \mathrm{m}^{2}$ and $732 \mathrm{ind} / \mathrm{m}^{2}$ in 2001 and 2002, respectively; then $S$. plana with abundances of the order of 1836 and 827 and densities up to $3780 \mathrm{ind} / \mathrm{m}^{2}$ and $1808 \mathrm{ind} / \mathrm{m}^{2}$ in 2001 and 2002, respectively.

\section{The ecosystem after stopping wastewater discharge}

The number of individuals harvested amounts to 15968 (Table 1). There are 22 species belonging to four phyla. The Molluscan phylum is dominant (69.6\%), followed by that of the Annelids (28.9\%), and the Crustacea (1.4\%). Dominance by species shows that Hediste diversicolor dominates the settlement with an abundance of 4599 individuals and a density which reaches in some stations $2328 \mathrm{ind} / \mathrm{m}^{2}$, followed by Hydrobia ulvae with an abundance of 4495 and a density of up to $4200 \mathrm{ind} / \mathrm{m}^{2}$, Cerastoderma edule with an abundance of 3765 and a density of $6760 \mathrm{ind} / \mathrm{m}^{2}$ as well as Scrobicularia plana with an abundance of 2795 and a density of up to $2336 \mathrm{ind} / \mathrm{m}^{2}$. 
Table 1. Faunistic composition of the macrobenthos of the Oued Souss estuary by phylum during the period of wastewater discharge (2001 and 2002) and after their cessation (2003)

\begin{tabular}{|c|c|c|c|c|c|c|}
\hline \multirow[b]{2}{*}{ Specification } & \multicolumn{2}{|c|}{2001 Campaign } & \multicolumn{2}{|c|}{2002 Campaign } & \multicolumn{2}{|c|}{2003 Campaign } \\
\hline & $\begin{array}{c}\text { Total } \\
\text { Abundance }\end{array}$ & $\%$ & $\begin{array}{c}\text { Total } \\
\text { Abundance }\end{array}$ & $\%$ & $\begin{array}{c}\text { Total } \\
\text { Abundance }\end{array}$ & $\%$ \\
\hline Nemathelminthes sp. & & & 25 & 0.274 & 16 & 0.100 \\
\hline Annelids & 2459 & 21.82 & 1134 & 12.42 & 4615 & 28.9 \\
\hline Nemerte $s p$ & & & & & 1 & 0.006 \\
\hline Arenicola marina & & & 12 & 0.131 & 5 & 0.031 \\
\hline Capitella capitata & & & & & 1 & 0.006 \\
\hline Glycera tridactyla & 12 & 0.106 & 10 & 0.110 & 1 & 0.006 \\
\hline Heteromastus filiformis & & & & & 1 & 0.006 \\
\hline Hediste diversicolor & 2426 & 21.526 & 1112 & 12.178 & 4599 & 28.801 \\
\hline Lanice conchylega & & & & & 1 & 0.006 \\
\hline Nephtys hombergii & & & & & 1 & 0.006 \\
\hline Pectinaria koreni & 21 & 0.186 & & & 5 & 0.031 \\
\hline Molluscs & 8747 & 77.61 & 7682 & 84.13 & 11113 & 69.6 \\
\hline Aplysia punctate & & & & & 2 & 0.013 \\
\hline Cerastoderma edule & 378 & 3.354 & 72 & 0.789 & 3765 & 23.578 \\
\hline Donax trunculus & & & & & 21 & 0.132 \\
\hline Hydrobia ulvae & 6500 & 57.675 & 6730 & 73.70 & 4495 & 28.15 \\
\hline Macoma cumana & 33 & 0.293 & 53 & 0.580 & 35 & 0.219 \\
\hline Scrobicularia plana & 1836 & 16.291 & 827 & 9.057 & 2795 & 17.504 \\
\hline Crustaceans & 64 & 0.57 & 290 & 3.18 & 224 & 1.4 \\
\hline Bathyporeia sp & & & 48 & 0.526 & 48 & 0.301 \\
\hline Carcinus maenas & 4 & 0.035 & 6 & 0.066 & 17 & 0.106 \\
\hline Eurydice pulchra & 44 & 0.39 & 236 & 2.585 & 128 & 0.802 \\
\hline Gammarus marinus & & & & & 12 & 0.075 \\
\hline Haustorius arenarius & 15 & 0.133 & & & 10 & 0.063 \\
\hline Urothoe brevicornis & 1 & 0.009 & & & 9 & 0.056 \\
\hline
\end{tabular}

The composition of macrobenthic fauna and the abundance of these organisms changed during this campaign. There was an enrichment of the macrobenthic population in new species and there were four species dominate the population, in decreasing order: $H$. diversicolor, $H$. ulvae, $C$. edule and $S$. plana instead of three species during the discard period: $H$. ulvae, $H$. diversicolor and S. plana. These data show that the ecosystem experienced a significant ecological change in faunistic composition. The number of individuals harvested was significantly larger compared to the period when the ecosystem received wastewater. Nevertheless, the phylum of mollusks was still dominant, followed by that of Annelids and Crustaceans.

\section{Longitudinal distribution of species and biocenotic units}

\section{The ecosystem receiving wastewater discharge.}

The species populating the environment were divided into four groups of species, depending on their distance from the sea (Figure 2):

- the first group linked to the mouth of the estuary (radials $0,1,1 \mathrm{bis}$ ) and not sinking beyond 250 meters. It consists of the following species: Arenicola marina, Glycera tridactyla, Bathyporeia sp, Eurydice pulchra, Haustorius arenarius and Urothoe brevicornis; 


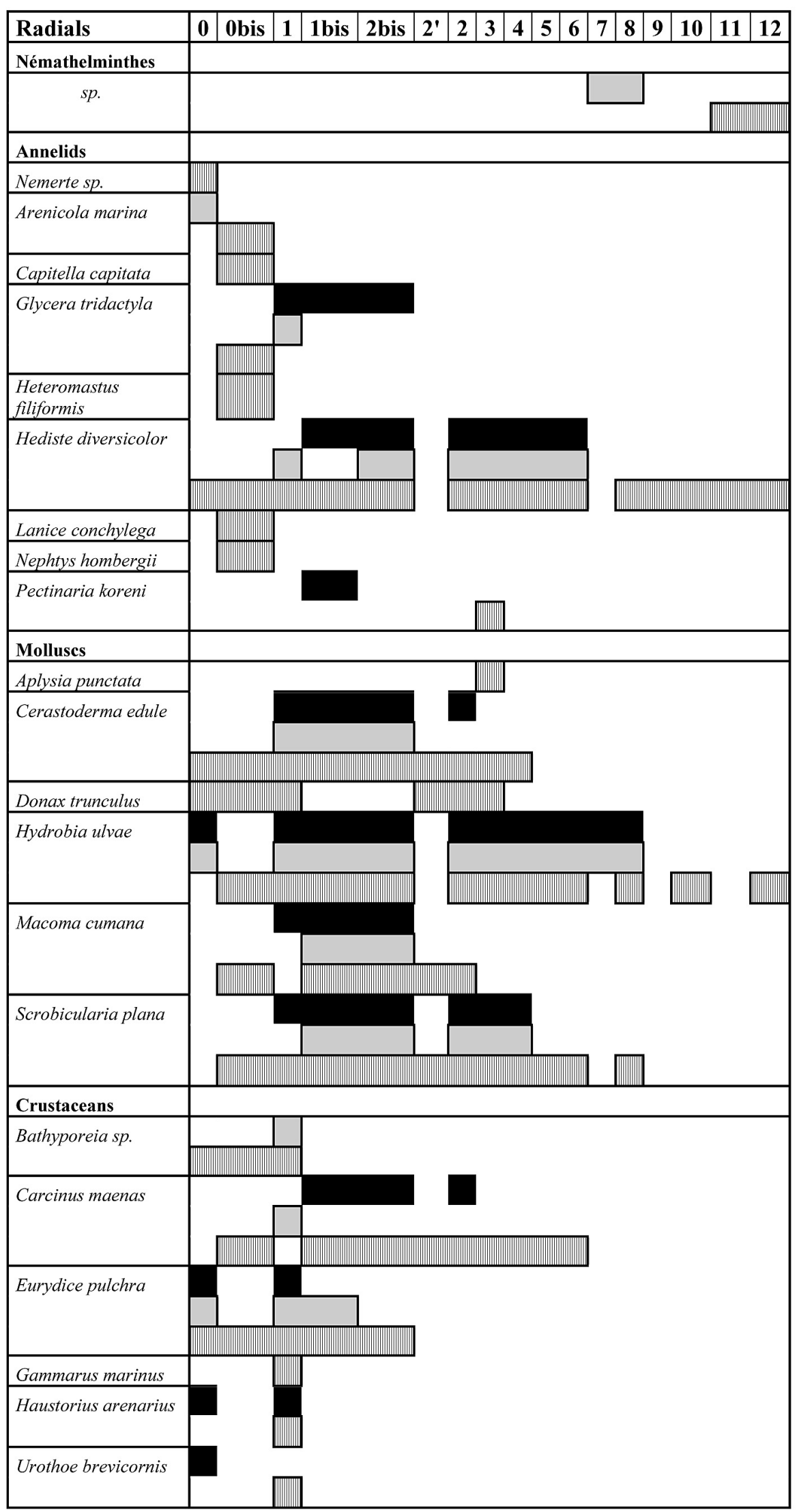

Figure 2. Longitudinal distribution of intertidal benthic macrofauna in the mouth of Oued Souss, Agadir Bay: during the discharge period (2001 and 2002) and after that period (2003)

$$
2001 \square 2002 \_2003 \text { لس }
$$


- the second group that is distributed on radials 1, 1bis, 2bis and 2. It is composed by Cerastoderma edule and Macoma cumana;

- the third group corresponding to species with very wide distribution on the estuary: Scrobicularia plana in radials: 1 to 4, Hediste diversicolor in radials: 1 to 6 and Hydrobia ulvae in radials: 0 to 8 ;

- the fourth group, spotted only in 2002, and represented by the parasitic nematode which is confined upstream of the estuary, at the level of radials 7 and 8 .
Regarding the stations beyond radial 8, they constitute an azo-zone.

The study on the coenotic affinity between settlements of different radials allowed us to separate $2-3$ groups of radials (Figure 3 ). Thus, in 2001, the dendrogram distinguishes (Figure 3a): a first group consisting of radials 0 and $1,1 \mathrm{bis}$, 2 and 2 bis; and a second group which associates radials $3,4,5,6,7$, and 8 . The latter has two subgroups (3-6 and 7-8), whereas in 2002, Figure 3 b shows three groups: Group 1 (radials $0,1,1$ bis and 2bis), Group 2 (radials 2, 3, 4, 5 and 6) and Group 3 (radials 7 and 8).

(a)

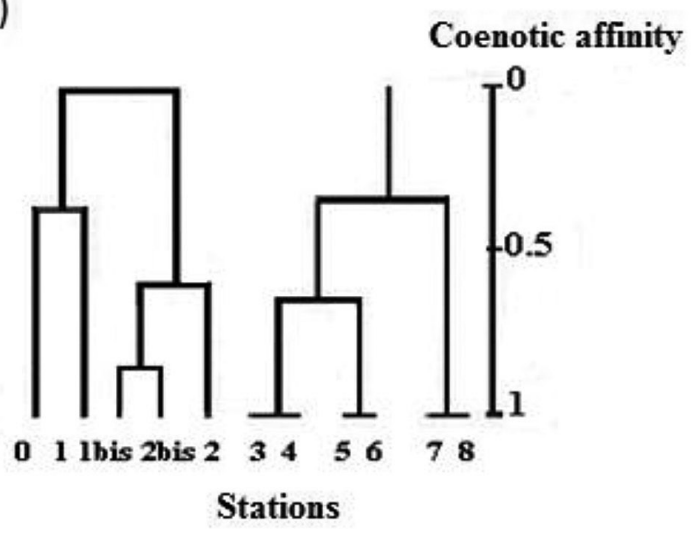

(b)

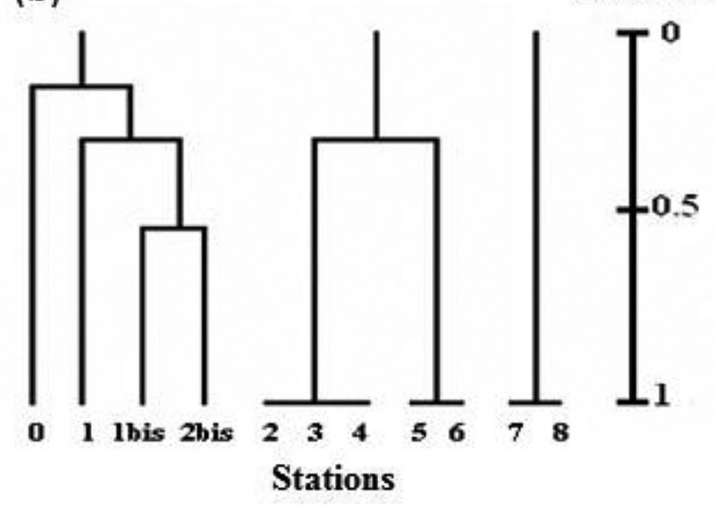

Coenotic affinity

(c)

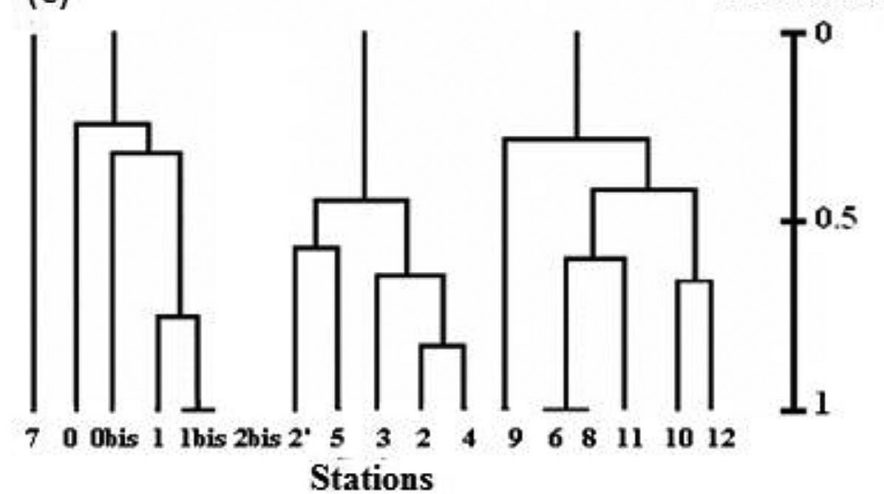

Stations

Figure 3. Hierarchical ascending classification of intertidal invertebrate settlements living during the period of wastewater discharge (a: 2001, b: 2002), and after (c: 2003) at the Oued estuary Souss (Bay of Agadir). 
The ecosystem after stopping wastewater discharge

The species composition and distribution, after discharges stopped, showed a change that was manifested by species enrichment, a longitudinal widening of their distribution area and the repopulation of the radials that were azoic during the discharge period. The distribution of species in the estuary enabled to distinguish four groups (Figure 2):

- Group 1. (Radials, close to the sea: 0, 0bis, 1). It is composed of: Arenicola marina, Capitella capitata, Glycera tridactyla, Heteromastus filiformis, Lanice conchylega, Nephthys hombergii, Bathyporeia sp., Gammarus marinus, Haustorius arenarius, Urothoe brevicornis, and finally Eurydice pulchra which populated also radials 1 bis and 2 bis;

- Group 2. It is constituted by Cerastoderma edule and Macoma cumana. It also includes Donax trunculus. This group has a widening of the distribution range of the species that compose it, since we note a penetration of $C$. edule in the estuary (station 4), as well as M. cumana which populates radial 2;

- Group 3. It is composed of species that populate the most radials. This is the case of S. plana (0 bis to 8), H. diversicolor and H. ulvae (radial 0 or 0 bis to 12). C. maenas (0bis to 6) can be included to these species. The species in this group have all expanded their range in the estuary.

- Group 4. It consists mainly of nematodes having migrated upstream of the estuary (radials 11 and 12).
In addition, some species are found exclusively in radial 3: Pectinaria koreni and Aplysia punctata.

In terms of affinity between settlements (Figure 3c), we can classify the radials into three groups, after stopping discharges in the estuary:

- Group 1, consisting of settlements from radials: 0, 0bis, 1, 1bis, 2bis;

- Group 2, counting of settlements from radials: 2,2 ', 3, 4, and 5;

- Group 3, associating the settlements of radials 6,8 and those of radials which were azoic during discharges: $9,10,11,12$.

\section{Species richness and biomass, before and after the end of wastewater discharge}

\section{Species richness}

During the period when the estuary received wastewater discharge, the number of species recorded during the harvest was 14. Figure 4 shows the specific richness for each radial. There is a negative correlation between this parameter and the distance of the radial with respect to the sea. After the cessation of rejections, the number of species harvested is 22. Thus, one records enrichment on almost all the radials of the estuary with the exception of radial 7 , which has become azoic, after the cessation of discharges. This last observation is surely in relation with the change of the river at this level of the estuary.

\section{Biomass}

Figure 5 shows the differences between the results obtained for the biomass of fauna recorded by radial during campaigns carried out before and after the cessation of discharges.

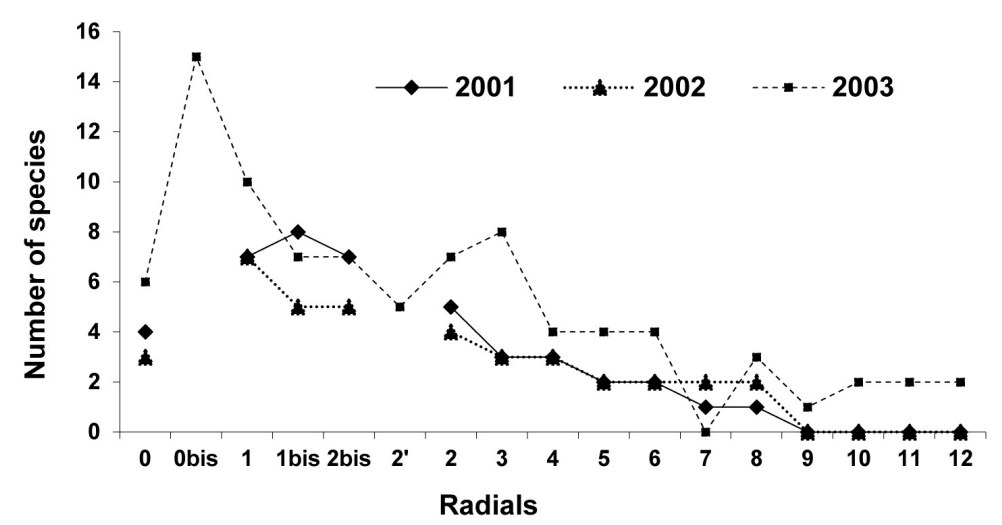

Figure 4. Variation of the species richness of the macrobenthos in the Oued Souss estuary by radial, before (2001 and 2002) and after (2003) the end of wastewater discharge 


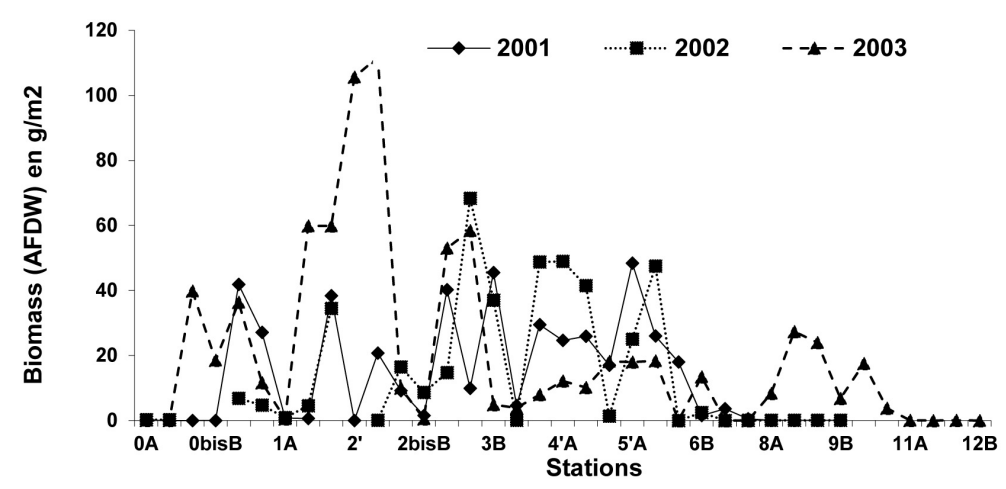

Figure 5. Variation of the total biomass of macrobenthos in the Oued Souss estuary by station [AFDW in $\left(\mathrm{g} / \mathrm{m}^{2}\right)$ ] before (2001 and 2002) and after (2003) the end of wastewater discharge.

The results show an increase in the biomass at radials 0 to 2 of the mouth after the cessation of the pollution, whereas for radials 3 to 6 , there is a decrease in the biomass. However, the average biomass calculated after cessation of discharges has increased significantly. It is $20.46 \mathrm{~g} / \mathrm{m}^{2}$ (in 2003) compared to $15.54 \mathrm{~g} / \mathrm{m}^{2}$ or $15.84 \mathrm{~g} / \mathrm{m}^{2}$ (respectively in 2001 or 2002) in the presence of wastewater discharge.

The biomass results by species (all radials combined) also enable to distinguish differences between the two periods (Table 2). Thus, during the first period (2001-2002), H. diversicolor has the largest biomass (43.64 to $55.84 \%$ ), followed by S. plana (38 to $35.75 \%$ ), C. edule $(13.32 \%$ to $2.53 \%$ ), and finally Hydrobia ulvae (1.67 to $2.25 \%$ ). The values quoted correspond to the results of the 2001 and 2002 surveys, respectively. In turn, after the end of wastewater discharge, the dominant species in biomass are in descending order: $C$. edule which represents $31.55 \%$ of the total biomass, followed by $H$. diversicolor $(23.35 \%)$, S. plana (22.6\%), Aplysia punctata $(10.55 \%)$ and then C. maenas (10.23\%).

\section{DISCUSSION}

\section{Settlement faunistic composition}

The campaigns that took place while the Oued Souss estuary was receiving wastewater (2001-2002) enabled to draw up the first inventory of the intertidal zoobenthic fauna in this ecosystem and to identify the structure of this settlement. Regarding faunal composition, we observe a year-to-year variation in the total abundance of the individuals surveyed, without affecting the order in which species are ranked in relation to their abundance dominance. In descending order Hydrobia ulvae, followed by Hediste diversicolor then Scrobicularia plana. The horizontal distribution shows a succession of three communities with regards to the coenotic affinity between the settlements. The first community occupies radials 0-2 bis (2001), or 0-2 (2002) while the second includes radials which constitute the central part of the estuary: $3,4,5,6$, then the last community consists of the species from radials 7 and 8, which are close to the discharges. Sometimes, the latter community has a certain affinity with the community of previous radials (2001) and sometimes it dissociates completely (2002). In a parallel study in which the granulometry and physico-chemistry of water in the estuary were treated (Gillet et al., 2003), it has been argued that in the absence of a true hyaline gradient at the level of the estuary of the Oued Souss, the grain size and the proximity of wastewater discharge seem to be the factors that most influence the distribution of species. We have indeed distinguished a first group composed by the radials of the mouth where the substrate is sandy (coarse sand to fine for radial 0 to $1 \mathrm{a}$, or sands silted for 2a and 2); a second group corresponding to the radials where the sediment becomes much muddier and clayey (radial: 2 or 3 to 6 ); finally, a third group of radials 7 and 8 , which corresponds to the zone where the influence of wastewater discharge is important and where the surface of the mud flat is very small.

After the cessation of discharges, the total abundance of the fauna is much greater, the abundance dominance has undergone modifications since $H$. diversicolor becomes the most abundant, followed by H. ulvae, Cerastoderma edule then S. plana. Differences are also observed at the level of the settlement structure if we continue referring to the coenotic affinity. Indeed, this 
Table 2. Cumulative biomass by species [AFDW in $(\mathrm{g})$ ] of the intertidal macrobenthos of the Oued Souss estuary, during the period of wastewater discharge (2001-2002) and after (2003), all stations being considered

\begin{tabular}{|c|c|c|c|c|c|c|}
\hline \multirow[b]{2}{*}{ Specification } & \multicolumn{2}{|c|}{2001 Campaign } & \multicolumn{2}{|c|}{2002 Campaign } & \multicolumn{2}{|c|}{2003 Campaign } \\
\hline & $\begin{array}{l}\text { Cumulative } \\
\text { biomass }(\mathrm{g})\end{array}$ & $\%$ & $\begin{array}{l}\text { Cumulative } \\
\text { biomass }(\mathrm{g})\end{array}$ & $\%$ & $\begin{array}{l}\text { Cumulative } \\
\text { biomass }(\mathrm{g})\end{array}$ & $\%$ \\
\hline \multirow{2}{*}{ Nemathelminthes sp. } & & & & & & \\
\hline & & & 0.011 & 0.003 & 0.011 & 0.001 \\
\hline \multicolumn{7}{|l|}{ Annelids } \\
\hline Nemerte sp. & & & & & 0.018 & 0.002 \\
\hline Arenicola. marina & & & 0.042 & 0.010 & 0.041 & 0.005 \\
\hline Capitella capitata & & & & & 0.000 & 0.000 \\
\hline Glycera tridactyla & 0.044 & 0.010 & 0.004 & 0.001 & 0.002 & 0.000 \\
\hline Heteromastus filiformis & & & & & 0.000 & 0.000 \\
\hline Hediste diversicolor & 189.940 & 43.640 & 230.084 & 55.846 & 176.733 & 23.349 \\
\hline Lanice conchylega & & & & & 0.009 & 0.001 \\
\hline Nephtys hombergii & & & & & 0.033 & 0.004 \\
\hline Pectinaria koreni & 1.210 & 0.278 & & & 0.034 & 0.005 \\
\hline \multicolumn{7}{|l|}{ Molluscs } \\
\hline Aplysia punctata & & & & & 79.898 & 10.556 \\
\hline Cerastoderma edule & 5.960 & 13.317 & 10.418 & 2.529 & 238.824 & 31.552 \\
\hline Donax trunculus & & & & & 1.117 & 0.148 \\
\hline Hydrobia ulvae & 7.279 & 1.672 & 9.277 & 2.252 & 9.651 & 1.275 \\
\hline Macoma cumana & 1.120 & 0.257 & 3.514 & 0.853 & 0.927 & 0.122 \\
\hline Scrobicularia plana & 165.480 & 38.020 & 147.324 & 35.758 & 171.232 & 22.623 \\
\hline \multicolumn{7}{|l|}{ Crustaceans } \\
\hline Bathyporeia sp. & & & & & 0.654 & 0.086 \\
\hline Carcinus maenas & 12.050 & 2.769 & 10.881 & 2.641 & 77.423 & 10.229 \\
\hline Eurydice pulchra & 0.160 & 0.037 & 0.435 & 0.106 & 0.293 & 0.039 \\
\hline Gammarus marinus & & & 0.010 & 0.002 & 0.001 & 0.000 \\
\hline Haustorius arenarius & 0.002 & 0.000 & & & 0.011 & 0.002 \\
\hline Urothoe brevicornis & 0.000 & 0.000 & & & 0.004 & 0.000 \\
\hline
\end{tabular}

parameter allows us to distinguish three communities: a group at the mouth (radial: 0 to 2 bis), a second group in the central part of the estuary (radial: 2' to 5) and a third group which associates radials upstream (6 and 8) to those which were azoic during discharges (radial: 9 to 12). Radial 7 is discarded because at high tide, the seawater does not reach it any more. This change in the course of water is surely due to the cessation of discharges. The preexisting species have seen their range extend at the level of the estuary. This enlargement is due either to a colonization of these stations by young specimens of $H$. diversicolor, from $H$. ulvae, S. plana, or C. edule, or to a migration of these species to these new territories from the nearby habitats. Indeed, several authors (Mettam C., 1981; Lewis et al., 2001; Meziane \& Retière, 2001) report that the populations of $H$. diversicolor have a great ability to migrate at any point in their life cycle. With the exception of Macoma balthica, which is known for its frequent migrations (Perkins, 1974), mollusks are not very mobile. Three species call for particular comments:

- H. ulvae is famous not only for the high densities it reaches, but also for its controversial behavior. Authors indicate for this species a tidal cycle of burial, feeding in a pelagic medium (by flotation) then after falling on the ground, crawling (Newell, 1962; Anderson, 1971). On the other hand, other authors think that buoyancy is accidental, and that burial is a reaction against dehydration or predators (Barnes, 1981). The dispersion of this small gastropod would then be due only to the planktonic larval stage or passive transports, by the movements of the water (rotation of the adults on the substrate). Thus, after the cessation of the discharges, one can think about a tidal (floating), exploring the upstream stations. Be that as it may, the life span of this species is rarely more than a year and a half. In the literature it was reported that eggs encapsulated by 3 to 5 are observable from March to December 
and larval arrival occurs three weeks later (Muus, 1986). The expansion of the range of the species could also be explained by a new recruitment.

- S. plana, meanwhile, can make rare displacements in the horizontal direction (Hugues, 1970). Six months after the cessation of the discharges, the longitudinal widening of the range of the scrobiculars upstream is surely due to the installation of juveniles especially as this species presents, at the level of Oued Souss, two recruitment periods, from February to March and from late spring to early autumn (Bergayou \& Moukrim, 2005).

- C. edule also has a longitudinal widening of its distribution. As this species is living and growing in the sand, the cessation of the flow of wastewater in the estuary and the absence of another flow of fresh water in the estuary make the estuary more susceptible to marine hydrodynamics; hence, the deposit of a thin layer of sand and the installation of cockles a little further upstream (station 4). This hypothesis is based on the findings of a study at the level of the Canche estuary (northern France) (Dobroniak, 2000). The author explains that the settlements have certain stability over time, but migrations could be caused by the morpho-sedimentary upheavals induced, among other things, by the hydro dynamism and the geographical modifications of the Canche bed, the distribution of the biocenoses being essentially due to these physical factors (Dobroniak, 2000). Another argument is that the cockle is fairly sensitive to pollution, whatever its nature, according to a study in the Kinneil mudflats at the Forth estuary in Scotland (Mac Lusky, 1981). In these mud flats, which receive domestic, chemical or oil effluents, $C$. edule does not live in the sediment near the source of pollution, but is found $1.5 \mathrm{~km}$ from the effluents; and its maximum abundance is between 1.5 and $2.2 \mathrm{~km}$. In the present study on Oued Souss, this bivalve was found about two kilometers away from the source of pollution during discharges and its presence in 2003 in stations 3 and 4 is surely a consequence of the cessation of pollution.

In marine habitats, the phenomenon of restocking may depend on the free surfaces in question. For small areas, restocking is rapid and is done through a large variety of pioneer opportunistic species (Frid, 1989). For large areas, this repopulation can take months or years (Beukema et al., 1999). However, in a more recent study on the Cochin estuary of the tropical monsoon (India) (Rehitha et al., 2017) in which the sites that were or were not subject to dredging were compared, the authors highlighted the dominance of a single opportunistic benthic taxon that has settled in sites that had been dredged.

In this study, only the most downstream, marine-influenced stations experienced enrichment of new species. Upstream, the preexisting species have expanded their range. Similar results were reported on mudflats at Dutch Wadden Sea (Holland) (Beukema et al., 1999) and at Clonakily Bay, West Cork, (Ireland) (Lewis et al., 2001).

\section{Species richness}

Species richness was very low during the discharge period (14 species). Indeed, the number of species usually encountered in an estuary varies between 30 and 300 species. By way of comparison, authors have identified 32 species in the Loire estuary (Marchand, 1972; Robineau, 1986), 66 species in the Gironde estuary (Bachelet et al., 1981), 86 species in the Tagus estuary (Portugal) (Calvario, 1984), 264 species in the Bou Regreg estuary (Morocco) (Elkaim, 1974; 1976) or 52 species in the same estuary (Cheggour, 1988) after the Sidi Mohamed Ben Abdellah dam was commissioned in 1974 in the Bou Regreg basin and, in more recent studies, 37 species for the macrobenthos in the Smir lagoon in northern Morocco (Chaouti \& Bayed, 2005) and 57 taxa at the Khnifiss lagoon in southern Morocco (Lefrere et al., 2015). In the case of the Oued Souss estuary, the factors explaining this faunistic poverty are numerous: the freshwater inputs are very low because of the rare rainfall; this phenomenon is further accentuated by the installation of dams on the bed of the Oued, the most important of which is that of Aoulouz, $150 \mathrm{~km}$ upstream; in addition, the pollutant load is important because of urban discharges. Moreover, the lesser diversity of habitats (lack of rocky substrates, absence of sea grass beds) at the level of the estuary and its geographical position with a certain number of species which are at the southern limit of their distribution area explain this low species richness to some extent.

After the discharges, we counted 22 taxa. This observation puts the index on the negative 
effect of wastewater. However, this is a punctual result and should be taken with caution. Indeed, the species richness, which reflects stability, depends first and foremost on breaks in the climax of the ecosystem: maximum under average conditions, it decreases when disturbances are important and / or frequent (Connell, 1978). Secondly, the biological regulation of communities can only take place when the resources of the environment are fully utilized. Thus, when the environment remains stable for a very long time, resources become restricted and competition sets the limits of the number of species. The dynamic equilibrium is then reached (Huston, 1994; Pickett \& Cadenasso, 1995): the composition of the settlement varies according to the colonizations and results in a stable global structure determined by the physical environment and predation.

\section{Biomass}

The average biomass of the harvested fauna has varied. Thus, during the discharge period, it was $15.54 \mathrm{~g} / \mathrm{m}^{2}$ then $15.84 \mathrm{~g} / \mathrm{m}^{2}$ (in 2001 and 2002, respectively), with three species (H. ulvae, $H$. diversicolor and $S$. plana) which constitute the majority: 83.33 to $93.85 \%$, respectively, for the first two campaigns. These species are typical of Atlantic estuaries and are known for their tolerance (Gonzalez Oreja \& Sais Salinas, 2003). On the other hand, after the cessation of discharges, the average biomass was $20.56 \mathrm{~g} / \mathrm{m}^{2}$, of which $78.79 \%$ is represented in abundance by the four dominant species: $H$. diversicolor, $S$. plana, C. edule and H. ulvae. In order of dominance in biomass, the cockles come first with $31.52 \%$ of the total biomass. This is important and can be explained by the spectacular expansion in terms of numbers marked by the species. The other three species represent only $47.25 \%$ of the total biomass. If we consider the two species S. plana or H. diversicolor, their total abundance marks an increase of 1.5 to 3.4 times and 1.89 to 4.13 compared to the period of discharges, respectively for the two species. This increase is not accompanied by an increase in the biomass of these two species. Knowing their diets: mixed for S. plana (detritivore at low tide and suspensivore at high tide) and detritivore for $H$. diversicolor, we can think of a slimming of individuals in relation to the decline in the rate of organic matter noted in the sediment after the cessation of discharges (Ait Alla et al., 2006a). In a comparative study on $H$. diversicolor populations of Bou Regreg estuary (Morocco) (Gillet, 1986) with populations of this species from the Ythan (Scotland) estuary (Chambers \& Milne, 1975), Gillet (1986) reaches the same findings by emphasizing that for the neighboring densities, the highest biomasses corresponded to the populations of the stations close to the sewage outlets, and thus whose sediment contained a high level of organic matter.

Still, regarding the biomass, our results are comparable to those obtained in the Gironde estuary (France) where $90 \%$ of the average biomass (estimated at $10.4 \mathrm{~g} / \mathrm{m}^{2}$ ) consists of the biomasses of three dominant species (Bachelet et al., 1981). In comparison, in a study on mud flats at Duch Wadden Sea (Holland), an average biomass of $26.6 \mathrm{~g} / \mathrm{m}^{2}$ (Beukema, 1976) and a biomass of $13.2 \mathrm{~g} / \mathrm{m}^{2}$ in the Lynher estuary are reported (England) (Warwick \& Price, 1975). |However, it should be noted that this type of comparison is difficult because the methods used are not always homogeneous and the environmental conditions are rarely taken into account.

\section{CONCLUSION}

This study proposes an inventory of the intertidal benthic system of the Oued Souss estuary from a structural point of view. First of all, it allowed us to acquire a qualitative (species list, species richness) and quantitative (abundance, biomass, species density) database of intertidal benthic macrofauna. It represents a reference state. This tool was used to respond to the requests for information about the quality of the environment immediately after the cessation of wastewater discharge and could serve as a basis for conducting impact studies in the future.

However, while the spatial dimension is relatively well documented, the temporal dimension was not taken into account in this study. Finally, we suggest a continuation of the investigations along the estuary according to a monthly or seasonal monitoring in order to be able to establish the structure of the benthic population over time (seasonal and interannual variations) and to see the new state of equilibrium which must be currently reached by the different zoobenthic populations of the estuary. 


\section{REFERENCES}

1. Agnaou M., Ait Alla A., Ouassas M., Bazzi Lh., El Alami Z., Moukrim A., 2014. Assessment of organochlorine pesticides contamination of Oued Souss estuary (South of Morocco): Seasonal variability in sediment and a detritivore annelid Nereis diversicolor. J. Mater. Environ. Sci. 5 (2), 581-586.

2. Ait Alla, A., Gillet, P., Deutsch, B., Moukrim, A., Bergayou, H., 2006a. Population dynamics and secondary production of Hediste Diversicolor (O. F. Müller, 1776), (Polychaeta, Nereidae) in estuary of the oued Souss, Bay of Agadir, Morocco. Estuar. Coast. Shelf. S. 70, 633-642.

3. Ait Alla, A., Mouneyrac C., Durou C., Moukrim A., Pellerin J., 2006b. Tolerance and biomarkers as useful tools for assessing environmental quality in the Oued Souss estuary (Bay of Agadir, Morocco). Comp Biochem Physiol C Toxicol. Pharmacol. 143(1), 23-29.

4. Anajjar, E., Chiffoleau, J.F., Bergayou, H., Moukrim, A., Burgeot, T., Cheggour, M., 2008. Monitoring of Trace Metal Contamination in the Souss Estuary (South Morocco) Using the Clams Cerastoderma edule and Scrobicularia plana. Bull. Environ. Contam. Toxicol. (80),283-288.

5. Anderson A., 1971. Intertidal activity, breeding and the floating habit of Hydrobia ulvae in the Ythan estuary. J. Mar. Biol. Ass. U. K.., (51), 423-437.

6. Bachelet G., Bouchet J.M., Lissalde J.P., 1981. Les peuplements benthiques de la Gironde : biomasse, productivité et évolution structurale. Oceanis, 6 (6), 593-620.

7. Barnes R.S.K., 1981. Behavioural activities and ecological strategies in the intertidal gastropod Hydrobia ulvae in Feeding and survival strategies of estuarine organisms, N.V. Jones, W.F. Wolff Eds., Plenum Press. New York \& London, 79-90.

8. Bergayou, H. \& A. Moukrim, 2005. Cerastoderma edule (Linné, 1758) et Scrobicularia plana (da Costa, 1778) : étude comparative de la croissance des mollusques et des générations annuelles dans l'estuaire de l'Oued Souss (sud-ouest du Maroc) sous climat aride. Haliotis, (34), 49-58

9. Bergayou, H., Moukrim, A., Mathieu, M., Gimazane, J.P., 2008. Reproduction of the cockle Cerastoderma edule (Linné, 1758) in the estuary of Oued Souss (southwestern Morocco). Ibérus, 26 (1): 29-42.

10. Bergayou, H., Mouneyrac, C., Pellerin, J. Moukrim, A. 2009. Oxidative stress responses in bivalves (Scrobicularia plana, Cerastoderma edule) from the Oued Souss estuary (Morocco). Ecotoxicol. Environ. Safety, 72 (3): 765-769.

11. Beukema J.J., 1976. Biomass and species richness of the macrobenthic animals living on the tidal flats of the Dutch Wadden Sea. Neth. J. Sea Res (10), 236-261.
12. Beukema J.J., Flach E.C., Dekker R., Starink M., 1999. A long-term study of the recovery of the macrozoobenthos on large defaunated plots on a tidal plot in the Wadden Sea. J. Sea. Res. (42), 235-254.

13. Calvario J., 1984. Etude préliminaire des peuplements benthiques intertidaux (substrats meubles) de l'estuaire du Tage (Portugal) et sa cartographie. Publ. Museum. e laboratorio Zoologico Antropologico., (11), 187-205.

14. Chambers M.R. \& Milne H., 1975. Life cycle and production of Nereis diversicolor O. F. Müller in the Ythan Estuary Scotland. Estu. Cost. Mar. Sci., (3), 133-144.

15. Chaouti, A\& A. Bayed, 2005 Diversité taxonomique et structure de la macrofaune benthique des substrats meubles de la lagune de Smir (nord-ouest du Maroc). Travaux de l'Institut Scientifique, Rabat, série générale. A. Bayed \& F. Scapini (éditeurs), (4), 33-42

16. Cheggour M., 1988. Contribution à l'étude d'un milieu paralique : l'estuaire du Bou Regreg (côte atlantique marocaine). Thèse de doctorat, Ecole Normale Supérieure Takaddoum, Rabat.

17. Connell J.H., 1978. Diversity in tropical rain forests and coral reefs. Science, (199), 1302-1310.

18. Dakki M., El Agbani M.A., Qninba A., Benhhoussa A., 1995. Recensement hivernal d'oiseaux d'eau au Maroc : janvier 1995. Documents de l'Institut Scientifique, Rabat (18).

19. Dobroniak C., 2000. Géomorphologie, Hydrodynamisme, et écologie tempéré macrotidal : l'Arthie, Manche Orientale, France. Thèse de doctorat de Géographie physique, Université du Littoral, Wimereux.

20. El Bekkay M., 2013. Contribution à l'étude du rôle des aires protégées en tant qu'outil pour la conservation de la biodiversité et la valorisation des territoires : Cas du site Ramsar de l'estuaire de l'oued Massa (Parc National Souss Massa), Thèse de doctorat, Université Ibn Zohr, Agadir.

21. El Hamidi F., Banaoui A., Azdi M., Kaaya, A., Zekhnini, A., Moukrim, A. 2002. Utilisation de la réponse de quatre biomarqueurs d'exposition chez les bivalves Perna perna et Donax trunculus pour l'évaluation de la pollution dans la baie d'Agadir (sud du Maroc). Haliotis, (32), 21-32.

22. Elkaim B., 1974. Contribution à l'étude écologique d'un estuaire atlantique marocain : l'estuaire du Bou Regreg. Thèse de doctorat, Université Bordeaux I, Bordeaux.

23. Elkaim B., 1976. Bionomie et Ecologie des peuplements des substrats meubles d'un estuaire atlantique marocain : 1'estuaire du Bou Regreg. II. Unités indicatrices peu liées à l'étagement ou médiolittorales. Vie Milieu, Vol. XXVI, fasc. 2, série B, 199-241. 
24. Elliot J.M. \& Descamps H. 1973. Guide pour l'analyse statistique des échantillons d'invertébrés benthiques. Ann. Limn., (2), 79-120.

25. Frid C.L.J., 1989. The role of recolonization in benthic communities, with special reference to the interpretation of predato-induced effects. J. Exp. Mar. Biol. Ecol. (126), 163-171.

26. Gillet P., 1986. Contribution à l'étude écologique des Annélides Polychètes de l'estuaire de Bou Regreg (Maroc). Thèse de Doctorat, Université d'Aix-Marseille, Marseille.

27. Gillet P., Gormann E., Tallec P., Moukrim A., Mouloud M., Ait Alla A., Bergayou H., \& Kaaya A., 2003. Impacts des rejets urbains sur les communautés benthiques intertidales de l'embouchure de l'Oued Souss, baie d'Agadir, Maroc. J. Rech. Océanogr. (28), 39-44.

28. Gonzalez Oreja J.A. \& Sais Salinas J.I. 2003. Recovery simulations of grossly polluted sediments in the Bilbao Estuary. Mar. Poll. Bull., (46), 42-48.

29. Hugues R.N., 1970. Population dynamics of the bivalve Scrobicularia plana (Da Costa) on an intertidal mud-flat in North Wales. J. Anim. Ecol., (39), 333-356.

30. Huston, M. A. 1994. Biological Diversity: The Coexistence of Species on Changing Landscapes. Cambridge University Press, 708 pp.

31. Lance G.N. \& Williams W.T. 1967. A general theory of classification sorting strategies. I. Hierarchical System Computing Journal, (9), 373-380.

32. Lefrere L., Ouassas M., Guillois B., Gillet P., Moukrim A. (2015). Macrobenthic community structure of soft-bottom sediments in the Khnifiss lagoon, South of Morocco J. Mater. Environ. Sci. 6 (11), 2226-2236

33. Legendre P. \& Legendre L. 1998. Numerical Ecology, 2nd English edition. Developments in environmental modelling, Elsevier Science BV, Ed., Amsterdam. 853 p.

34. Lewis L.J., Davenport J., Kelly T.C., 2001. A study of the impact of a pipeline construction on estuarine benthic invertebrate communities. Est. Coast. Shelf. Sci., (55), 213-221

35. Mac Lusky D.S., 1981. The estuarine ecosystem. Blackie ed., Glasgow \& London, 150 p.

36. Marchand J., 1972. Bionomiebenthique de l'estuaire de la Loire. Rev. Trav. Inst. Pêches mar., 36 (1), $47-67$.
37. Mettam C., 1981. Survival strategies in estuarine nereids. In: Feeding and survival strategies of estuarine organisms, Jones N.V.\& Wolff W.J., eds. Plenum Press, London, 65-77.

38. Meziane T. \& Retière C. 2001. Role of biotic interactions seasonal migrations of the macrozoobenthos living in the upper tidal-flat of the Mont-Saint-Michel bay, France. Oceanol. Acta. 24 (6), 1-7.

39. Mimouni, R, Ait Alla, A. Anajjar, E.M., Finance, C., Moukrim, A., 2002. Impacts du rejet des eaux usées sur la qualité microbiologique des plages de la baie d'Agadir (Maroc). Journal Européen d'Hydrobiologie, 33 (1), 115-123.

40. Moukrim A., Chiffoleau J.F., Cheggour M., Burgeot, T., 2008. Changes in the sediment trace metal contamination after the commissioning of a municipal wastewater treatment plant in the Souss estuary (South Morocco). Bulletin of Environmental Contamination and Toxicology, 80 (6), 549-554

41. Muus B.J., 1967. The fauna of Danish estuaries and lagoons. Distribution and ecology of dominating species in the shallow reaches of the mesohaline zone. Meddr. Danm. Fisk. -og Havunders, 5 (1), 3-316.

42. Newell R.C., 1962. Behavioural aspects of the ecology of Perengia (=Hydrobia) ulvae. Proc. Zool. Soc. Lond., (138),49-75.

43. Oubrou W. \& El Bekkay M., 2014. Rapport sur la reproduction de l'Ibis chauve dans la région de Sous-Massa. Haut-Commissariat aux Eaux et Forêts et à la Lutte Contre la Désertification. Direction Régionale des Eaux et Forêts et de Lutte Contre la Désertification du Sud-Ouest.

44. Perkins E., 1974. The biology of estuaries and coastal waters. Academic Press, London, 678 p.

45. Pickett S.T.A. \& Cadenasso M.L., 1995. Landscape Ecology: spatial heterogeneity in ecological systems. Science, (269), 331-334.

46. Rehitha, T.V., Ullas, N., Vineetha, G., Benny, P. Y. Madhu N.V., and C. Revichandran, 2017. Impact of maintenance dredging on macrobenthic community structure of a tropical estuary. Ocean Coast Manage (144), 71-82.

47. Robineau B., 1986. Les peuplements benthiques de l'estuaire de la Loire. Distribution spatio-temporelle. Reproduction et croissance des Bivalves Tellinidés. Thèse de Doctorat, Université de Nantes, 298 p

48. Warwick R.M., R. Price 1975. Macrofauna production in an estuarine mudflat. J. Mar. Biol. Ass. U. K., (55), 1-18. 